\title{
Synthesis and Study of Some 4-Chlorophenoxy Methyl Substituted amido1,3,4-Oxadiazoles, 1,3,4- Thiadiazoles and 1,2,4-Triazoles from 4-Chloro phenoxy acetic acid
}

Khalid M. Daoud

Department of Pharmaceutical

Chemistry

College of Pharmacy

University of Mosul

Received

18 / 03 / 2013
Mudhar A. Othman*

Department of Chemistry College of Education for girls University of Mosul

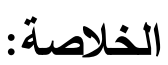

حُضِّرَ في هذا البحث عدد من معوضات 4,3,1-أوكسادايازول و 4,3,1-ثايادايازول و 4,2,1-نرايازول ذات الفعالية البيولوجية المتوقعة من خلاد تفاعل كلوريد 4-كلوروفينوكسي

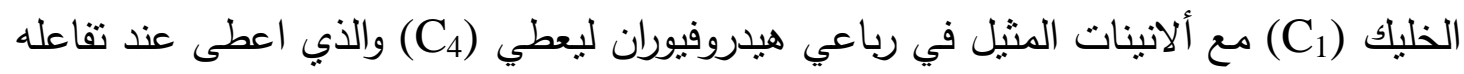

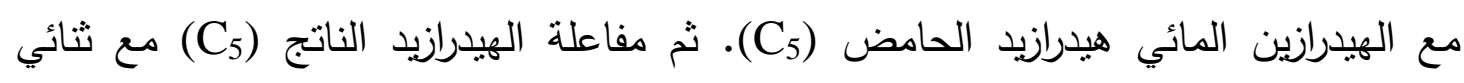

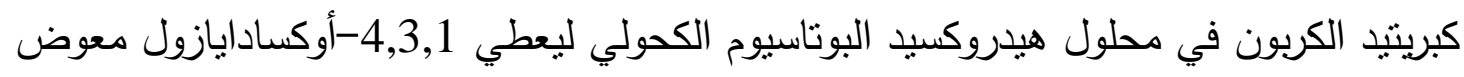
بينما اعطى تفاعل الهيدرازيد $\left(C_{6}\right)$ الفنيل معوضي الثايوسميكاربازيد $)$

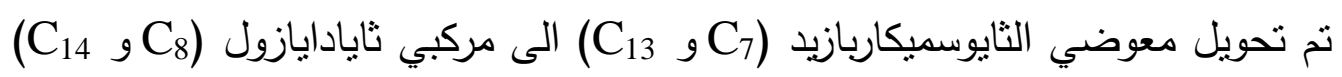
ومركبي ترايازول (C) , C C

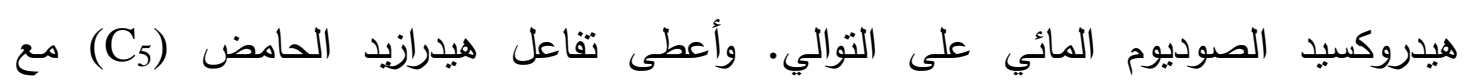
ثايوسيانات الامونيوم ثايوسميكاربازيد معوض (C) $\left(C_{10}\right)$ و حُضِّرَ منه ثايادايازول (C $\left.C_{12}\right)$

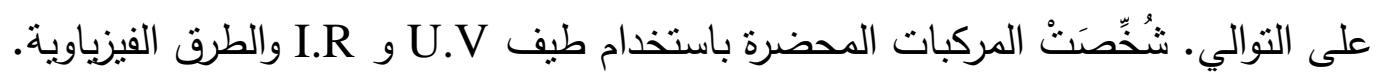
Abstract: 
In this paper the synthesis of some substituted 1,3,4-oxadiazole, 1,3,4-thiadiazoles and 1,2,4-triazoles is reported. 4-Chlorophenol was treated with chloroacetic acid to give 4-chlorophenoxy acetic acid $\left(\mathrm{C}_{1}\right)$ which was reacted with thionyl chloride followed by methyl alaninate $\left(\mathrm{C}_{3}\right)$ to give the methyl ester $\left(\mathrm{C}_{4}\right)$. The ester $\left(\mathrm{C}_{4}\right)$ was converted to corresponding hydrazide $\left(\mathrm{C}_{5}\right)$ by it's reaction with hydrazine hydrate in ethanol. Hydrazide $\left(\mathrm{C}_{5}\right)$ was treated with carbon disulfide in alcoholic potassium hydroxide to give substituted $1,3,4$-oxadiazole $\left(\mathrm{C}_{6}\right)$, while the reaction of hydrazide $\left(\mathrm{C}_{5}\right)$ with ally isothiocyanate and with phenyl isothiocyanate gave substituted thiosemicarbazides $\left(\mathrm{C}_{7}\right)$ and $\left(\mathrm{C}_{13}\right)$ respectively.

Thiosemicarbazides $\left(\mathrm{C}_{7}\right.$ and $\left.\mathrm{C}_{13}\right)$ were converted to substituted 1,3,4-thiadiazoles $\left(\mathrm{C}_{8}\right.$ and $\left.\mathrm{C}_{14}\right)$ and 1,2,4-triazoles $\left(\mathrm{C}_{9}\right.$ and $\left.\mathrm{C}_{15}\right)$ by their reactions with concentrated sulfuric acid and with aqueous sodium hydroxide solution respectively. The reaction of acid hydrazide $\left(\mathrm{C}_{5}\right)$ with ammonium thiocyanate gave thiosemicarbazide $\left(\mathrm{C}_{10}\right)$ from which substituted 1,3,4-thiadiazole $\left(\mathrm{C}_{11}\right)$ and 1,2,4-triazole $\left(\mathrm{C}_{12}\right)$ were synthesized by it's reaction with concentrated sulfuric acid and with aqueous sodium hydroxide solution respectively.

The structures of the synthesized compounds were established on the bases of U.V and I.R spectrum analysis and physical measures.

Keywords: Thiosemicarbazide, 1,3,4-oxadiazole, 1,3,4-thiadiazole, 1,2,4-triazole.

\section{Introduction:}

Five member heterocyclic compounds showed various type of biological activities such as 2,5-disubstituted 1,3,4-oxadiazoles (I) which are associated with diverse antimicrobial biological activities ${ }^{(1)}$.<smiles>[R]c1nnc(CCC(=O)c2ccc(Br)cc2)o1</smiles>

(I)

3, 5- Diaryl- 1,2,4-oxadiazole derivatives showed significant reduction of tumor cell count as well as tumor weight, where as life span of the treated mice also increased, this derivatives was prepared of 2-chlorobenzamidoxime with substituted benzoyl chloride in pyridine ${ }^{(2)}$.

A series of novel 1,2,4-oxadiazole and 1,3,4-oxadiazole derivatives were synthesized and evaluated for in-vitro antibacterial and antifungal activity $^{(3,4)}$. 1,2,4-oxadiazoles possess analgesic properties ${ }^{(5)}$. In another research 1,2,4-oxadiazole compounds were prepared from reaction of 
hydroxylamine with chloroform in pyridine ${ }^{(6)}$. The thiosemicarbazide and 1,3,4-oxadiazole (II). Possess antihypertensive and diuretic activities ${ }^{(7)}$.<smiles>Nc1nnc(-c2nn(-c3ccccc3)c3nc(-c4ccccc4)cc(=O)n23)o1</smiles>

(II) $\operatorname{Kumar}^{(8)}$.

In another search 1,3,4-oxadiazole was prepared by G.V. Suresh

In recent years 1,2,4-triazoles and its derivatives have received considerable attention owing to their synthetic and effective biological importance. The heterocycles bearing a symmetrical triazoles moiety were reported from cyclization of Benzamidoguanidine with a solution of sodium in absolute alcohol ${ }^{(9)}$, treated of thiosemicarbazides with concentrated sodium hydroxide solution ${ }^{(10)}$ or reaction of thiocarbohydrazide with carboxylic acid in pyridine ${ }^{(11)}$. The compounds (III) and (IV) shows antiviral ${ }^{(12)}$ and antileishmanial activities ${ }^{(13)}$ respectively.<smiles>[R3]c1cc(NC(=O)CNc2nc([AsH2])n[nH]2)c([R])c([R])c1[R3]</smiles><smiles>Nc1ccc(C2=Nn3c(nnc3-c3cccnc3)SC(c3cccc(Br)c3)=C2)cc1</smiles>

Substituted 1,3,4-thiadiazole showed various biological activity like antibacterial $^{(14)}$ as (V) and Anti-microbial ${ }^{(15)}$ as (VI).<smiles>Cc1nnc(SC(=O)NC=[Al])s1</smiles>

(V)<smiles>[R]c1nn2c(-c3cccnc3)nnc2s1</smiles>

(VI)

\section{Experimental:}

\section{a. Measurements:}

Melting points were determined in open capillary tubes in a Thomas Hoover melting point apparatus and are uncorrected. U.V- 
Visible/Shimadzu-1601 and Infrared spectrum were recorded on FT-IR , Shimadzu/157.

\section{b. Preparations:}

4-Chlorophenoxy acetic acid $\left(C_{1}\right)^{(16)}$ :

A solution of sodium hydroxide $(4.5 \mathrm{~g} / 25 \mathrm{ml})$ was added slowly to mixture of 4-chlorophenol (6.63 g, $0.049 \mathrm{~mole})$ and chloroacetic acid (4.7 g, 0.049 mole). The mixture was heated with stirring for (30 minutes) to evaporate most of the solvent, then water $(150 \mathrm{ml})$ was added and the solution acidified with concentrated hydrochloric acid. The resultant precipitate was filtered and recrystallized from ethanol / water. m.p. 154$155^{\circ} \mathrm{C}$ (Lit. ${ }^{(16)} 154-155^{\circ} \mathrm{C}$ ).

\section{Methyl alaninate hydrochloride $\left(C_{2}\right)^{(17)}$ :}

In a dry round bottom flask $(250 \mathrm{ml})$ in ice bath, alanine $(8.9 \mathrm{~g}, 0.1$ mole $)$ in absolute methanol $(100 \mathrm{ml})$ was added, thionyl chloride ( $8 \mathrm{ml}, 0.11$ mole) was added slowly with stirring for (30 minutes), the mixture was refluxed for (15 minutes) the solution become clear, the solvent was evaporated under reduced pressure, The solid product was recrystallized from ethanol,m.p. $112^{\circ} \mathrm{C}$ (Lit. ${ }^{(17)} 105-107^{\circ} \mathrm{C}$ ).

\section{Methyl alaninate $\left(C_{3}\right)^{(18)}$ :}

A mixture of methyl alaninate hydrochloride $(12.5 \mathrm{~g}, 0.1$ mole $)$ in methylene dichloride $(100 \mathrm{ml})$ in dry conical flask $(250 \mathrm{ml})$, dry ammonia gas was bubbled through the mixture with stirring (ammonia gas generated by a concentrated ammonium hydroxide in round bottom flask through anhydrous calcium chloride trap) by glass dropper in to the mixture, the precipitate of ammonium chloride, was separated by filtration, the filtrate was taken in a beaker, the solvent was evaporated to give oily methyl alaninate with characteristic amine odor. Tables $(1,2)$.

\section{Methyl-N-(4-chlorophenoxy acetyl) alaninate $\left(C_{4}\right)^{(19)}$ :}

A mixture of 4-chlorophenoxy acetic acid $\left(\mathrm{C}_{1}\right)(2.47 \mathrm{~g}, 0.024$ mole $)$ and thionyl chloride ( $2 \mathrm{ml}, 0.027$ mole) was heated until the formation of a clear solution. The solution then cooled in an ice-bath, followed by the addition of dry tetrahydrofuran $(10 \mathrm{ml})$. Methyl alaninate $\left(\mathrm{C}_{3}\right)(2.47 \mathrm{~g}$, 0.024 mole) was added slowly to the acid chloride solution and the mixture then refluxed for (15 minute). The colorless oil was formed upon the addition of water $(25 \mathrm{ml})$ and $20 \%$ sodium bicarbonate solution. The residue oily ester was separated. Tables $(1,2)$.

\section{4-chlorophenoxy acyl alanine hydrazide $\left(C_{5}\right)^{(20)}$ :}

A mixture of methyl ester $\left(\mathrm{C}_{4}\right)(2.81 \mathrm{~g}, 0.01$ mole) and hydrazine hydrate $(95 \%, 2.5 \mathrm{ml}, 0.05 \mathrm{~mole})$ in $(50 \mathrm{ml})$ absolute ethanol was 
refluxed for ( 2 hours). The mixture was cooled to room temperature then the solvent evaporate under reduced pressure. The precipitate was filtered and recrystallized from ethanol. Tables $(1,2)$.

\section{5-(Phenoxy methyl substituted amido)-1,3,4-oxadiazole-2-thiol $\left(C_{6}\right){ }^{(21)}$ :}

4-Chlorophenoxy acyl alanine hydrazide $\left(\mathrm{C}_{5}\right)(2.81 \mathrm{~g}, 0.01$ mole $)$ was dissolved in solution $(0.56 \mathrm{~g}, 0.01$ mole of potassium hydroxide in $150 \mathrm{ml}$ of ethanol 96\%). Carbon disulphide (6 ml, 0.1 mole) was added as pushes, the mixture was heated under reflux for ( 3 hours) until the evolution of hydrogen sulphide was stopped. The solvent was evaporated under reduced pressure, the product cooled and poured on ice-water (50 $\mathrm{ml})$. Acidified with dilute $\mathrm{HCl}$ to $(\mathrm{pH}=5-6)$, solid product $\left(\mathrm{C}_{6}\right)$ was obtained by filtration and purified by recrystallization from ethanol. Tables $(1,2)$.

\section{1-(4-Chlorophenoxy acyl alanoyl)-4-substituted thiosemicarbazides $\left(C_{7}, C_{13}\right)^{(10)}$ :}

The hydrazide $\left(\mathrm{C}_{5}\right)(0.55 \mathrm{~g}, 0.002$ mole $)$ was mixed with $(0.002$ mole) from (phenyl isothiocyanate or allyl isothiocyanate) in absolute ethanol $(25 \mathrm{ml})$. The mixture was refluxed for (6 hours), the solvent was evaporated under reduced pressure. The precipitates were filtered and recrystallized from ethanol. Tables $(1,2)$.

\section{1-(4-Chlorophenoxy methyl substituted amido) thiosemicarbazide $\left(C_{10}\right)^{(19)}$ :}

A mixture of hydrazide $\left(\mathrm{C}_{5}\right)(2.81 \mathrm{~g}, 0.01$ mole $)$, ammonium thiocyanate $(0.76 \mathrm{~g}, 0.05$ mole $)$ in ethanol $(50 \mathrm{ml})$ was refluxed for $(3$ hours). The solvent was evaporated and the precipitate filtered, recrystallized from ethanol. Tables $(1,2)$.

\section{2-Amino-5-(4-Chlorophenoxy methyl substituted amido)-1,3,4-} thiadiazole $\left(C_{8} C_{11}, C_{14}\right)^{(18)}$ :

The thiosemicarbazides $\left(\mathrm{C}_{7}, \mathrm{C}_{10}\right.$ or $\left.\mathrm{C}_{13}\right)(0.005$ mole $)$ was dissolved in concentrated sulfuric acid $(5 \mathrm{ml})$ with cooling. The reaction mixtures were stirred well, kept at room temperature for ( 2 hours), then poured onto crushed ice, concentrated ammonium hydroxide was added, the precipitated solids filtered, washed with water and recrystallized from ethanol to give $\left(\mathrm{C}_{8}, \mathrm{C}_{11}, \mathrm{C}_{14}\right)$. Tables $(1,2)$.

3-(4-Chlorophenoxy methyl substituted amido) -4-substituted-1,2,4triazole-5-thiol $\left(C_{9}, C_{12}, C_{15}\right)^{(22)}$ :

The thiosemicarbazide $\left(\mathrm{C}_{7}, \mathrm{C}_{10}\right.$ or $\left.\mathrm{C}_{13}\right)(0.005$ mole $)$ was refluxed in $10 \%$ sodium hydroxide $(50 \mathrm{ml})$ for ( 3 hours), the mixture was cooled, poured into water and filtered. The filtrates was acidified with dilute 
hydrochloric acid to give the crude products $\left(\mathrm{C}_{9}, \mathrm{C}_{12}\right.$ and $\left.\mathrm{C}_{15}\right)$ which were filtered, washed with water and recrystallized from ethanol. Tables $(1,2)$.

Table 1: physical data of compounds $\left(\mathrm{C}_{1}-\mathrm{C}_{15}\right)$

\begin{tabular}{|c|c|c|c|c|}
\hline Comp. No. & m.p. ${ }^{\circ} \mathrm{C}$ & Yield $\%$ & Color & Molecular Formula \\
\hline $\mathrm{C}_{1}$ & $154-155$ & 65 & white & $\mathrm{C}_{8} \mathrm{H}_{7} \mathrm{ClO}_{3}$ \\
\hline $\mathrm{C}_{2}$ & 112 & 92 & white & $\mathrm{C}_{4} \mathrm{H}_{10} \mathrm{ClNO}_{2}$ \\
\hline $\mathrm{C}_{3}$ & Oily & 47 & colorless & $\mathrm{C}_{4} \mathrm{H}_{9} \mathrm{NO}_{2}$ \\
\hline $\mathrm{C}_{4}$ & Oily & 64 & brown & $\mathrm{C}_{12} \mathrm{H}_{14} \mathrm{ClNO}_{4}$ \\
\hline $\mathrm{C}_{5}$ & 158 & 71 & white & $\mathrm{C}_{11} \mathrm{H}_{14} \mathrm{ClN}_{3} \mathrm{O}_{3}$ \\
\hline $\mathrm{C}_{6}$ & $130-131$ & 16 & brown & $\mathrm{C}_{12} \mathrm{H}_{12} \mathrm{ClN}_{3} \mathrm{O}_{3} \mathrm{~S}$ \\
\hline $\mathrm{C}_{7}$ & $129-130$ & 96 & white & $\mathrm{C}_{15} \mathrm{H}_{19} \mathrm{ClN}_{4} \mathrm{O}_{3} \mathrm{~S}$ \\
\hline $\mathrm{C}_{8}$ & $140-142$ & 52 & grey & $\mathrm{C}_{15} \mathrm{H}_{17} \mathrm{ClN}_{4} \mathrm{O}_{2} \mathrm{~S}$ \\
\hline $\mathrm{C}_{9}$ & $136-137$ & 47 & brown & $\mathrm{C}_{15} \mathrm{H}_{17} \mathrm{ClN}_{4} \mathrm{O}_{2} \mathrm{~S}$ \\
\hline $\mathrm{C}_{10}$ & $85-87$ & 33 & brown & $\mathrm{C}_{12} \mathrm{H}_{15} \mathrm{ClN}_{4} \mathrm{O}_{3} \mathrm{~S}$ \\
\hline $\mathrm{C}_{11}$ & $128-130$ & 52 & pale brown & $\mathrm{C}_{12} \mathrm{H}_{13} \mathrm{ClN}_{4} \mathrm{O}_{2} \mathrm{~S}$ \\
\hline $\mathrm{C}_{12}$ & $150-151$ & 32 & brown & $\mathrm{C}_{12} \mathrm{H}_{13} \mathrm{ClN}_{4} \mathrm{O}_{2} \mathrm{~S}$ \\
\hline $\mathrm{C}_{13}$ & $162-164$ & 77 & white & $\mathrm{C}_{18} \mathrm{H}_{19} \mathrm{ClN}_{4} \mathrm{O}_{3} \mathrm{~S}$ \\
\hline $\mathrm{C}_{14}$ & 267 dec. & 15 & white & $\mathrm{C}_{18} \mathrm{H}_{17} \mathrm{ClN}_{4} \mathrm{O}_{2} \mathrm{~S}$ \\
\hline $\mathrm{C}_{15}$ & $202-204$ & 59 & grey & $\mathrm{C}_{18} \mathrm{H}_{17} \mathrm{ClN}_{4} \mathrm{O}_{2} \mathrm{~S}$ \\
\hline
\end{tabular}

Table 2: spectral data of compounds $\left(\mathrm{C}_{1}-\mathrm{C}_{15}\right)$

\begin{tabular}{|c|c|c|c|c|c|c|}
\hline \multirow[b]{2}{*}{$\begin{array}{c}\text { Comp. } \\
\text { No. }\end{array}$} & \multirow[b]{2}{*}{$\begin{array}{l}\mathrm{U} . \mathrm{V} \lambda \\
\max .\end{array}$} & \multicolumn{5}{|c|}{$v \mathrm{~cm}^{-1}$} \\
\hline & & $\mathrm{N}-\mathrm{H}$ & $\stackrel{\mathrm{O}}{\mathrm{C}-} \mathrm{N}$ & $\stackrel{\mathrm{O}}{\mathrm{C}} \mathrm{O}$ & $\mathrm{C}=\mathrm{N}$ & $\mathrm{C}=\mathrm{S}$ \\
\hline $\mathrm{C}_{1}$ & 236 & --- & --- & 1706 & --- & --- \\
\hline $\mathrm{C}_{2}$ & 256 & 3423 & --- & 1745 & --- & --- \\
\hline $\mathrm{C}_{3}$ & 290 & 3423 & 1541 & 1683 & --- & --- \\
\hline $\mathrm{C}_{4}$ & 292 & 3422 & 1595 & 1735 & --- & --- \\
\hline $\mathrm{C}_{5}$ & 234 & 3208 & 1667 & --- & --- & --- \\
\hline $\mathrm{C}_{6}$ & 227 & 3447 & 1636 & --- & 1596 & 1238 \\
\hline $\mathrm{C}_{7}$ & 226 & 3504 & 1668 & --- & --- & 1217 \\
\hline $\mathrm{C}_{8}$ & 274 & 2430 & 1596 & --- & 1490 & --- \\
\hline $\mathrm{C}_{9}$ & 257 & 3089 & 1646 & --- & 1454 & 1231 \\
\hline $\mathrm{C}_{10}$ & 345 & 3425 & 1601 & --- & --- & 1208 \\
\hline $\mathrm{C}_{11}$ & 255 & 3311 & 1635 & --- & 1492 & --- \\
\hline $\mathrm{C}_{12}$ & 273 & 3443 & 1595 & --- & 1490 & 1235 \\
\hline $\mathrm{C}_{13}$ & 227 & 3244 & 1681 & --- & --- & 1252 \\
\hline $\mathrm{C}_{14}$ & 206 & 3454 & 1603 & --- & 1552 & --- \\
\hline $\mathrm{C}_{15}$ & 227 & 3449 & 1635 & --- & 1490 & 1239 \\
\hline
\end{tabular}




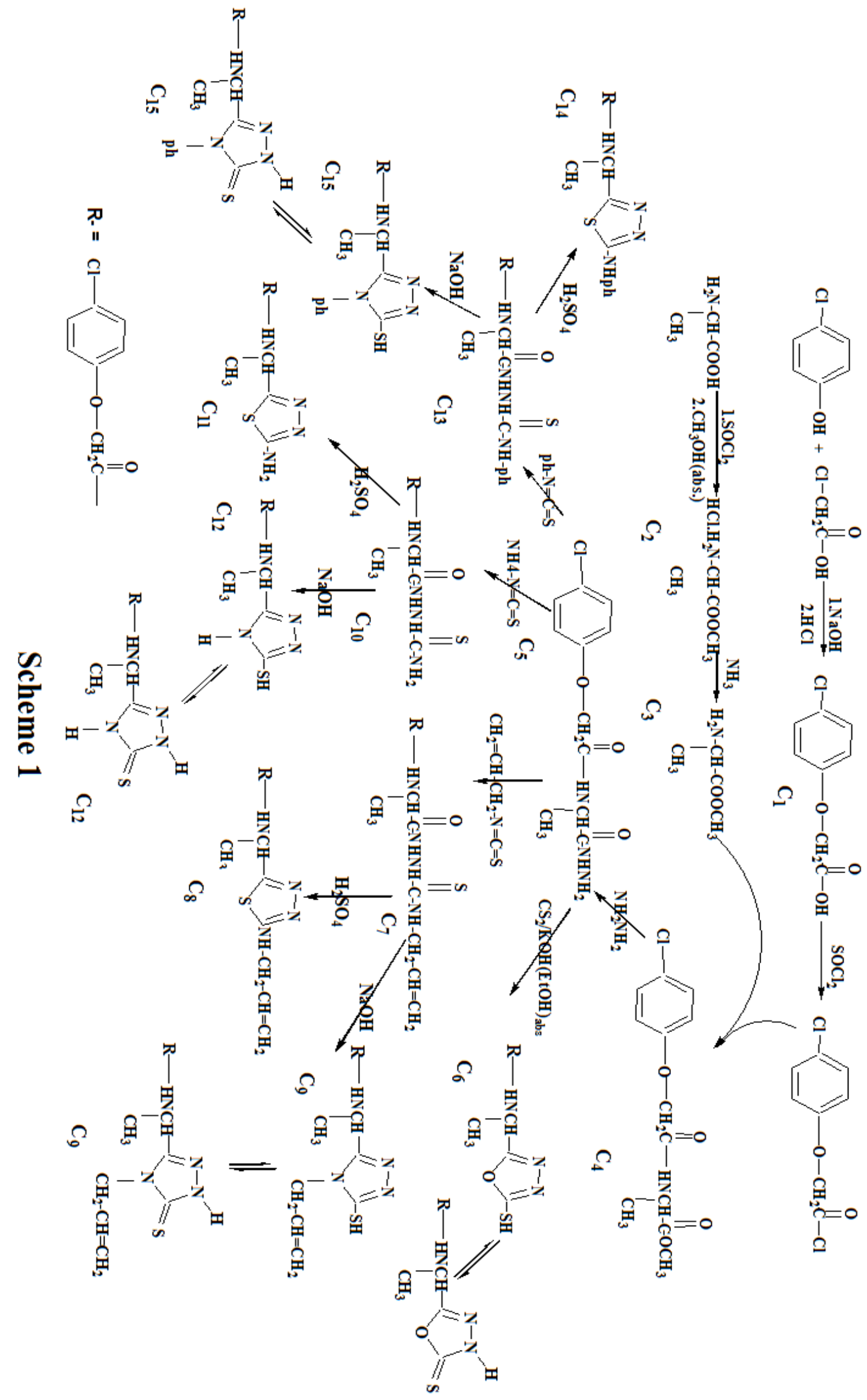




\section{Results and Discussion:}

In this paper the synthesis of substituted 1,3,4-oxadiazole, 1,3,4thiadiazoles and 1,2,4-triazoles is reported (Scheme 1). 4-Chlorophenoxy acetic acid $\left(\mathrm{C}_{1}\right)$ was treated with thionyl chloride to give the corresponding acid chloride, which reacted with methyl alaninate $\left(\mathrm{C}_{3}\right)$ [obtained from esterification of alanine by absolute methanol/thionyl chloride then neutralized with ammonia] to produce methyl $\mathrm{N}$-(4Chlorophenoxy acetyl) alanine $\left(\mathrm{C}_{4}\right)$.

The I.R spectrum of compound $\left(\mathrm{C}_{1}\right)$ show absorption at $1706 \mathrm{~cm}^{-1}$ due to $(\mathrm{C}=\mathrm{O}$ acid $)$ while the $(\mathrm{C}=\mathrm{O})$ absorption for ester $\left(\mathrm{C}_{4}\right)$ appeared at $1735 \mathrm{~cm}^{-1}$. UV-Visible spectrum of $\left(\mathrm{C}_{4}\right)$ showed bands at $(292 \mathrm{~nm})$. The ester $\left(\mathrm{C}_{4}\right)$ was converted to acid hydrazide $\left(\mathrm{C}_{5}\right)$ by it's reaction with hydrazine hydrate, the I.R spectrum for hydrazide show absorptions at $3208 \mathrm{~cm}^{-1}(\mathrm{~N}-\mathrm{H})$ and $1667 \mathrm{~cm}^{-1}$ for $(\mathrm{C}=\mathrm{O})$. UV-Visible spectrum of $\left(\mathrm{C}_{5}\right)$ showed bands at $(234 \mathrm{~nm})$. The acid hydrazide $\left(\mathrm{C}_{5}\right)$ was treated with was treated with carbon disulfide ethanolic potassium hydroxide to give substituted 1,3,4-oxadiazole $\left(\mathrm{C}_{6}\right)$ and with isothiocyanate compounds to give substituted thiosemicarbazides $\left(\mathrm{C}_{7}, \mathrm{C}_{10}\right.$ and $\left.\mathrm{C}_{13}\right)$. The I.R spectrum of substituted 1,3,4-oxadiazole $\left(\mathrm{C}_{6}\right)$ showed absorptions at $1636 \mathrm{~cm}^{-1}(\mathrm{C}=\mathrm{O})$, $1596 \mathrm{~cm}^{-1}(\mathrm{C}=\mathrm{N})$ and $1238 \mathrm{~cm}^{-1}$ due to $(\mathrm{C}=\mathrm{S})$. UV-Visible spectrum of $\left(\mathrm{C}_{6}\right)$ showed bands at $(227 \mathrm{~nm})$. The I.R spectrum of thiosemicarbazides $\left(\mathrm{C}_{7}, \mathrm{C}_{10}\right.$ and $\left.\mathrm{C}_{13}\right)$ showed absorptions at $1668-1681 \mathrm{~cm}^{-1}$ for $(\mathrm{C}=\mathrm{O})$ and 1217-1252 $\mathrm{cm}^{-1}$ for $(\mathrm{C}=\mathrm{S})$. UV-Visible spectrum of $\left(\mathrm{C}_{7}, \mathrm{C}_{10}\right.$ and $\left.\mathrm{C}_{13}\right)$ showed bands at (226-345 $\mathrm{nm})$.

The substituted thiosemicarbazides $\left(\mathrm{C}_{7}, \mathrm{C}_{10}\right.$ and $\left.\mathrm{C}_{13}\right)$ were treated with concentrated sulfuric acid and with aqueous sodium hydroxide solution to give substituted 1,3,4-thiadiazoles $\left(\mathrm{C}_{8}, \mathrm{C}_{11}\right.$ and $\left.\mathrm{C}_{14}\right)$ and substituted 1,2,4-triazoles $\left(\mathrm{C}_{9}, \mathrm{C}_{12}\right.$ and $\left.\mathrm{C}_{15}\right)$ respectively. The I.R spectrum of substituted 1,3,4-thiadiazoles $\left(\mathrm{C}_{8}, \mathrm{C}_{11}\right.$ and $\left.\mathrm{C}_{14}\right)$ showed absorption at $1490-1552 \mathrm{~cm}^{-1}(C=N)$. UV-Visible spectrum of $\left(C_{8}, C_{11}\right.$ and $\left.C_{14}\right)$ showed bands at (206-274 nm). The I.R spectra of substituted 1,2,4-triazoles $\left(\mathrm{C}_{9}, \mathrm{C}_{12}\right.$ and $\left.\mathrm{C}_{15}\right)$ showed absorptions at $1454-1490 \mathrm{~cm}^{-1}(\mathrm{C}=\mathrm{N})$ and 1231$1239 \mathrm{~cm}^{-1}$ for $(\mathrm{C}=\mathrm{S})$. UV-Visible spectrum of $\left(\mathrm{C}_{9}, \mathrm{C}_{12}\right.$ and $\left.\mathrm{C}_{15}\right)$ showed bands at (227-273 nm). Table (2).

\section{References:}

1) Sahu V. K.R.; Singh, A. K. and Yadav, D., Int. J. ChemTech Res., 3(3),1362-1372 (2011).

2) Kundu, M.; Singh, B.; Ghosh, T.; Singh, J.; Maity,T.K., Ind. J. Pharm Edu Res., 45(3), 267-271(2011).

3) Tale R. H.; Rodge, A.H.; Keche, A.P.; Hatnapure, G.D.; Padole, P.R.; Gaikwad, G.S.; Turkar, S.S., J. Chem. Pharm. Res., 3(2),496505 (2011). 
4) Kumar S., J. Pharm. Sci., 9(1),53-59 (2010).

5) Srivastava R.M. and Seabra G.M., J. Braz. Chem. Soc., 8(4), 397405 (1997).

6) Koryakova A. G.; Ivanenkov, Y.A.; Ryzhova, E.A.; Bulanova, E.A.; Karapetian, R.N.; Mikitas, O.V.; Katrukha, E.A.;. Kazey, V.I.; Okun, I.; Kravchenko, D.V.; Lavrovsky, Y.V.; Korzinov, O.M. and Ivachtchenko, A.V., Med. Chem. Lett. 18, 3661-3666 (2008).

7) Ali, K. A.; Ragab, E.A.; Farghaly, T.A. and Abdalla, M.M., Acta Poloniae Pharmaceutica- Drug Research, 68(2), 237-247 (2011).

8) Kumar, G.V. S.; Rajendraprasad, Y.; Mallikarjuna, B.P.; Chandrashekar, S.M. and Kistayya, C., European Journal of Medicinal Chemistry, 45, 2063-2074 (2010).

9) Kadadevar, D.; Chaluvaraju, K.C.; Niranjan, M.S.; handrashekar, C.; Santosh, K.M.; Nagaraj, M.H.; Smitha, M. and Krishna, C., Int.J. ChemTech Res., 3(3),1064-1069 (2011).

10) Hussain, S.; Sharma, J. and Amir M., E-Journal of Chemistry, 5(4), 963-968 (2008).

11) Geetha A.S.; Vijayaraj, R.; Kumar, T.R.; Anand, R.S., International Journal of Research in Pharmaceutical and Biomedical Sciences, 2(1), 155-159 (2011).

12) Bele, D.S. and Singhvi, I., Asian Journal of Biochemical and Pharmaceutical Research, 1(2), 88-101 (2011).

13) Kamal, M.; Shakya. A. K. and Jawaid T., IJBR, 2(1), 41-61( 2011).

14) Singh, k. A.; Mishra, G. and Jyoti, K., Journal of Applied Pharmaceutical Science, 01 (05); 44-49 (2011).

15) Omprakash, G.; Anjaneyulu, Y.; Subramanian, N.S.; Ramadevi, M.; Gupta, V.R.M. and Vijayalakshmi, G., RJPBCS, 2(1), 410-418 (2011).

16) Smith, T.V. and Waldron, N.M., "Vogel's Elementary Practical Organic Chemistry Preparation" $3^{\text {rd }}$ Ed., Longman group Ltd., London, p 316 (1980).

17) Al-naimi, K.H Yousif., Ph.D. Thesis, College of Education, University of Mosul (2000). (In Arabic).

18) Ahmad, A.K., Ph.D. Thesis, College of Education, University of Mosul (1998). (In Arabic).

19) Othman, M.A., M.Sc. Thesis, College of Education, University of Mosul (2000). (In Arabic).

20) Abdel-Aziz, H.A.; Elsaman, T.; Attia, M.I. and Alanazi, A.M., Molecules, 18, 2084-2095 (2013).

21) Liu, Z. M.; Chen, Q.; Chen, C.N.; Tu, H.Y. and Yang, G.F., Molecules, 13, 1353-1360(2008).

22) Goswami, B.N.; Kataky, J.C.S. and Baruah, J.N., J. Heterocyclic Chem., 21, 1224(1984). 